\title{
MINERAL WOOL INSULATION FOR LOW TEMPERATURES
}

\author{
(Second Edition)
}

\section{COMMERCIAL STANDARD CS105-48}

[Supersedes CS105-43]

Effective Date for New Production From October 20, 1948

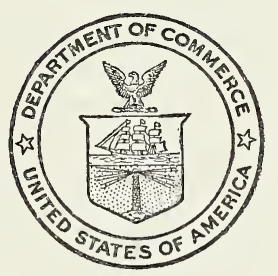

A RECORDED VOLUNTARY STANDARD OF THE TRADE

\section{UNITED STATES DEPARTMENT OF COMMERCE}

CHARLES SAWYER, Secretary 


\section{COMMODITY STANDARDS}

Simplified Practice Recommendations and Commercial Standards are developed by manufacturers, distributors, and users in cooperation with the Commodity Standards Division of the National Bureau of Standards. The purpose of Simplified Practice Recommendations is to eliminate avoidable waste through the establishment of standards of practice for stock sizes and varieties of specific commodities that currently are in general production and demand. The purpose of Commercial Standards is to establish standard methods of test, rating, certification, and labeling of commodities, and to provide uniform bases for fair competition.

The adoption and use of a Simplified Practice Recommendation or Commercial Standard is voluntary. However, when reference to a Commercial Standard is made in contracts, labels, invoices, or advertising literature, the provisions of the standard are enforceable through usual legal channels as a part of the sales contract.

A Simplified Practice Recommendation or Commercial Standard originates with the proponent industry. The sponsors may be manufacturers, distributors, or users of the specific product. One of these three elements of industry submits to the Commodity Standards Division the necessary data to be used as the basis for developing a standard of practice. The Division, by means of assembled conferences or letter referenda, or both, assists the sponsor group in arriving at a tentative standard of practice and thereafter refers it to the other elements of the same industry for approval or for constructive criticism that will be helpful in making any necessary adjustments. The regular procedure of the Division assures continuous servicing of each effective Simplified Practice Recommendation and Commercial Standard, through review and revision, whenever, in the opinion of the industry, changing conditions warrant such action. Simplified Practice Recommendations and Commercial Standards are printed and made available by the Department of Commerce, through the Government Printing Office.

\section{COMMERCIAL STANDARD.FOR MINERAL WOOL INSULA- TION FOR LOW TEMPERATURES}

On April 28, 1942, the Industrial Mineral Wool Institute proposed the establishment of a commercial standard for mineral wool insulation in low-temperature areas. This led to the development of a recommended standard, which was subsequently accepted by the trade and finally issued as Commercial Standard CS105-43, Mineral Wool; Loose, Granulated, or Felted Form, in Low-Temperature Installations.

A recommended revision of this standard, as proposed by the Indus. trial Mineral Wool Institute and approved by the standing committee, was circulated on July 14, 1948, to the trade for written acceptance. Those concerned have since accepted and approved the revised standard as shown herein.

Project Manager: J. W. Medley, Commodity Standards Division, National Bureau of Standards.

Technical Adviser: R. S. DILl, Building Technology Division, National Bureau of Standards. 
COMMERCIAL STANDARD CS105-48

for

\section{MINERAL WOOL INSULATION FOR LOW TEMPERATURES ${ }^{1}$}

(SECOND EDITION)

\section{PURPOSE}

1. The purpose of this commercial standard is $(a)$ to establish minimum specifications for insulating low-temperature areas with mineral wool for the guidance of manufacturers, distributors, installers, contractors, and users; $(b)$ to avoid delays and misunderstandings; and (c) to provide a standard basis for guaranteeing compliance and certifying quality of material.

\section{SCOPE}

2. This standard covers minimum physical and chemical requirements of mineral wool in loose, granulated, felt, industrial batt, and board or block forms. It includes thicknesses of insulation required for various operating temperatures, specifications for auxiliary materials, tests, installation requirements, and method of guaranteeing compliance with the standard.

\section{DEFINITIONS}

3. Mineral Wool.-Mineral wool insulation is rock, slag, or glass processed from a molten state into fibrous form.

3a. Loose.-Mineral wool as originally processed and collected in a fluffy mass without regard to form or dimension. nodules.

3b. Granulated.-Mineral wool mechanically processed into

3c. Felt.-Mineral wool with binder added, manufactured in semirigid form and furnished in flat sheets or rolls.

3d. Industrial batt. - Mineral wool without binder, manufactured in flat sheets or rolls.

3e. Board or block.-Mineral wool with binder, compressed to desired density and dried, with or without surface coating, forming a rigid material.

\footnotetext{
1 This standard includes requirements for installation.
} 


\section{MATERIAL}

4. Insulation.-The insulation shall be mineral wool in loose, granulated, felt, industrial batt, and board or block forms, and shall meet the following requirements:

4a. Thermal conductıvity. - The thermal conductivity $(k)$ shall not exceed $0.28 \mathrm{Btu}$ per hour per square foot per degree Fahrenheit for a thickness of 1 inch, when determined at a mean temperature of $50^{\circ} \mathrm{F}$. It shall be determined by the guarded hot-plate method, described under Methods of testing and reporting: XI, Commercial Standard CS131-46, ${ }^{2}$ or later revision.

4b. Density. - The installed density shall be as recommended by the manufacturer, and shall be not less than the minimum required to comply with the thermal conductivity specified in paragraph $4 \mathrm{a}$.

4c. Moisture sorption. - The mineral wool shall be moisturerepellent and shall have a moisture sorption less than 2 percent by weight when tested in accordance with the methods described under Methods of testing and reporting: VII, Commercial Standard CS131-46, or later revision.

4d. Corrosive properties.-The mineral wool shall not be corrosive to steel surfaces when tested in accordance with the methods described under Methods of testing and reporting: III, Commercial Standard CS131-46, or later revision.

4e. Odor.-The mineral wool shall be free from objectionable odor when tested in accordance with the methods described under Methods of testing and reporting: VIII, Commercial Standard CS131-46, or later revision.

4f. Fire resistance.-The mineral wool shall be rated incombustible when tested in accordance with the methods described under Methods of testing and reporting: VI, Commercial Standard CS13146, or later revision, except as modified by the presence of asphalt or other auxiliary material added for moisture resistance or installation purposes.

5. Auxiliary materials.-Materials used for installation or construction purposes shall meet the following requirements:

5a. Asphalt. - Asphalt shall be odorless and shall meet the following requirements:

\begin{tabular}{|c|c|c|c|}
\hline Property & Minimum & Maximum & ASTM test method \\
\hline $\begin{array}{l}\text { Softening point } \\
\text { Penatration at } 77^{\circ} \mathrm{F} \\
\text { Ductility at } 77^{\circ} \mathrm{F}\end{array}$ & $\begin{array}{c}180^{\circ} \mathrm{F} \\
20 \\
3\end{array}$ & $\begin{array}{c}200^{\circ} \mathrm{F} \\
35\end{array}$ & $\begin{array}{l}\text { a D } 36-26 \\
\text { a D } 5-25 \\
\text { a D } 113-44\end{array}$ \\
\hline
\end{tabular}

a Or later revision.

5b. Asphalt primer.-Asphalt primer shall be an emulsion or a cutback. The cutback shall meet the requirements of ASTM Specification D41-41, or later revision.

5c. Cold asphalt mastic (solvent type).-Asphalt mastic shall be composed of asphalt, a solvent, and mineral filler and shall have a

\footnotetext{
${ }^{2}$ Industrial mineral wool products, all types-testing and reporting, CS131-46, issued by the National Bureau of Standards, U. S. Department of Commerce, and available from the Superintendent of Documents, Government Printing Office, Washington 25, D. C.
} 
suitable consistency for trowel application. The solvent shall have a minimum flash point of $100^{\circ} \mathrm{F}$. The mastic shall have no objectionable odor after evaporation of the solvent.

5d. Asphalt emulsion.-Asphalt emulsion shall be composed of asphalt, water, and an emulsifying agent. Its consistency shall be suitable for brush or trowel application and it shall be free from objectionable odor when dry. It shall contain no substances favorable to mold or fungus growth.

5e. Reenforcing membranes.-Membranes for embedding in asphalt for vaporproofing or waterproofing layers built up on the job shall meet the following requirements:

(1) Saturated woven cotton fabric: ASTM Specification D17344 (or later revision), or other woven textile fabrics having equal strength characteristics.

(2) Asphalt-saturated rag felt: ASTM Specification D226-44 (or later revision), or papers of single or multilayer construction having equal tensile strength.

(3) Glass fiber or asbestos fiber mat shall be open mesh to permit penetration of asphalt.

5f. Vapor barrier membrane.-Membranes, such as treated papers, used for vapor barriers shall have adequate strength to resist handling. Their permeability to water vapor shall not be greater than 0.20 grain per hour per square foot when tested by the Dessicant Method at a temperature of $73^{\circ} \mathrm{F}$ and a relative humidity of 50 percent outside the test vessel. The test procedure shall be in accordance with ASTM Tentative method of test for water vapor permeability of sheet materials used in connection with thermal insulation, C214-47T or later revision.

5g. Vapor-permeable membrane.--Vapor permeable membrane shall be slater's felt or similar vapor-permeable water-repellent paper.

5h. Wood.-All wood used for supporting studs, joists, furring strips, skewers, or wherever it may be embedded in the insulation, shall be kiln-dried Douglas fir, yellow pine, cypress, or other suitable species, impregnated or treated with odorless materials to resist molds or rotting.

5i. Metal.-Steel or other metal for studs, furring, lath, or other supports shall be galvanized, sherardized, or otherwise well protected against corrosion.

5j. Cement.-Portland cement shall meet the requirements of AST'M Specification C150-46, or later revision.

5k. Hydraulic lime.-Hydraulic lime shall be high-calcium hydrated lime (type a), meeting the requirements of ASTM Specification C14142 , or later revision.

\section{INSULATION THICKNESS}

6. Refrigerated spaces.-All refrigerated compartments shall be insulated with mineral wool insulation to a thickness consistent with the local conditions. Thicknesses greater than the minimum stated below are recommended to reduce costs of refrigeration, but the choice will be modified by other factors such as climatic conditions, exposure, type of building, intended use, economics, etc. Table 1 shows recom- 
mended thicknesses for average conditions. Table 2 shows minimum recommended thicknesses.

TABLE 1. Recommended thicknesses for average operating conditions

\begin{tabular}{|c|c|}
\hline Temperature & Thickness \\
\hline $\begin{array}{l}{ }^{\circ} \mathrm{F} \\
\text { Down to } 35 \\
35 \text { to } 20 \\
20 \text { to } 5 \\
5 \text { to }-10 \\
-10 \text { and below. }\end{array}$ & $\begin{array}{l}\text { Inches } \\
3 \text { to } 4 \\
6 \\
8 \\
10 \\
12 \text { or more, as specified. }\end{array}$ \\
\hline
\end{tabular}

TABLE 2. Minimum thicknesses for various operating temperatures

\begin{tabular}{|c|c|}
\hline Temperature & Thickness \\
\hline $\begin{array}{l}\text { Down to } 45 \\
45 \text { to } 35 \\
35 \text { to } 25 \\
25 \text { to } 15 \\
15 \text { to } 5 \\
5 \text { to }-10 \\
-10 \text { and below.. }\end{array}$ & $\begin{array}{l}\text { Inches } \\
2 \\
3 \\
4 \\
5 \\
6 \\
8 \\
10 \text { or more, as specified. }\end{array}$ \\
\hline
\end{tabular}

\section{CONSTRUCTION}

7. General.-All material used in insulating refrigerated spaces and cold pipe lines in accordance with this standard shall be properly installed to give satisfactory performance and long service. The specific forms of mineral wool insulation shall be installed at proper density as recommended by the manufacturer.

8. Preparation of surface.

8a. Masonry.

(1) Monolithic concrete.-Concrete surfaces to which vapor barriers are to be applied must be smooth and even, free from paint, oil, soot, dust, dirt, loose particles, or anything that might prevent a satisfactory bond. Cracks or holes should be filled and the surface trued up with portland cement mortar. Before application of vapor barriers all concrete surfaces must be primed with an asphalt primer as directed below.

(2) Unit masonry.-Brick, tile, cement and cinder block, stone, etc. Before application of vapor barriers all surfaces shall be made plane and even by applying one or more coats of portland cement plaster to a thickness of at least $1 / 4$ inch over all high points. Plaster shall be mixed and applied as directed below.

(3) Plastering. - Surfaces to be plastered shall be roughened if necessary, to insure a good mechanical key and shall be free from oil, paint, soot, dust, dirt, loose particles, or anything that might interfere with the plaster bond. 
Immediately before application of the plaster, the surfaces shall be washed with clean water and allowed to dry until uniformly damp and suction is restored. The plaster shall be mixed in the proportion of one part portland cement, to which has been added not more than 10 percent (dry weight) hydraulic hydrated lime, and three parts of clean, sharp, mason's sand. Clean fresh water shall be added in the minimum amount needed to produce the required workability. The plaster shall be applied in one or more coats and floated to a smooth finish with a wooden straightedge.

(4) Asphalt primer. - All masonry or plaster surfaces to which a membrane-type vapor barrier is to be applied shall be primed with two coats of asphalt primer brushed or sprayed. The surfaces shall be dry when primed and the first coat of primer shall be dry before the second is applied.

8b. Wood surfaces.-Wood surfaces to which a vapor barrier will be applied shall be firm and smooth and any cracks, knotholes, or other open defects shall be blocked off or covered.

9. Vapor barrier.- In order to limit the infiltration of air and water vapor into the refrigerated space, a continuous vapor-barrier membrane shall be installed on the surfaces on the warm side of the insulation. The vapor-barrier membrane may be a manufactured product or built up on the job. In either case, when installed, its permeability shall conform to requirements of paragraph $5 \mathrm{f}$.

(1) Built-up vapor barrier shall consist of not less than two layers of asphalt or other suitable vapor-resistant material, applied by methods and in a physical form that will prevent vapor transmission as completely as possible. A reenforcing membrane shall be applied between layers. Suitable forms of asphalt that may be used are hot molten liquid applied by mopping, asphalt mastics applied by troweling, and some types of asphalt emulsions applied by spraying or troweling. The layers and the reenforcing membrane shall be firmly bonded together to form a continuous sheet over the surfaces covered. Special care shall be used to insure continuity at corners and junctions of walls with base floor and ceiling.

(2) Manufactured sheet materials used as vapor barriers shall meet the water-vapor permeability requirement and shall be applied to masonry or plaster surfaces with a suitable adhesive such as hot asphalt or cold asphalt mastic. All joints in sheet materials shall be lapped at least 3 inches and shall be cemented with an asphaltic or other waterproof lap cement. On wood surfaces the membranes may be applied with nails. All nailheads shall be caulked with mastic.

10. Foundations and general construction.-Foundations and general building constructions shall be sufficient to carry expected floor loads in the refrigerated space and shall afford a firm base for attaching 
vapor barriers and insulation supports. When the refrigerated space is supported directly on the ground and operating temperatures are below $32^{\circ} \mathrm{F}$, special precautions shall be taken to prevent freezing of the ground. When the water level in the surrounding area prevents natural drainage away from the foundation, air circulation through tile ducts in the foundations or other suitable means of preventing freezing shall be provided.

11. Insulation supports and application.-Supporting construction in walls, floors, and ceilings shall be provided where necessary to support and enclose the insulation or protect it from damage. In selecting the type of construction to be used, consideration should be given to the operating temperature control and comparative costs.

11a. Floors.-The floor insulation shall be laid over a solid base to which a vapor barrier has been applied. The construction shall be one of the types described below and illustrated in figures 1,2 , or 3 . Where the service requires a waterproof floor, a waterproof membrane shall be applied over the insulation. Over the membrane either a concrete wearing floor or a wood-slat and metal-pan construction shall be installed. Drains may be provided if needed.

(1) Cross-furring construction.-This shall consist of crossfurring two or more layers of treated wood strips at right angles as illustrated in figure 1. The insulation shall be applied in layers between the furring strips.

(2) Joist construction.-This shall consist of treated wood joists having a depth equal to the insulation thickness, as illustrated in figure 2. The applied insulation shall completely fill the space between the joists.

(3) Load-carrying mineral wool board construction.-This shall consist of rigid mineral wool board laid in hot asphalt as illustrated in figure 3. The insulation may be built up to the desired thickness by using two or more layers.

11b. Ceilings. - Ceiling insulation may be applied to the under side of a roof or structural ceiling but must be properly protected by a vapor barrier on the warm or upper side and supported mechanically by wood sheathing, metal lath and plaster, or similar interior finish attached to furring, ceiling joists, or other spacing members. (See figs. 4 and 5.) When construction details permit and headroom is available, ceiling insulation may be applied to the upper side of a structural ceiling, such as that of a cold-storage room built entirely within a building, or a ceiling under a peaked roof. (See fig. 6.) In such a case the wall insulation must extend up around the joists or structural members and be joined to the ceiling insulation. When metal I-beams extending through the insulation are used, they shall be insulated at least $2 \mathrm{ft}$. inward from the wall surface. When a fully suspended ceiling is preferred, only sufficient support for the insulation and finish should be provided. This shall be of light construction such as light steel channels, furring strips, and supporting metal lath. Vapor barriers shall be provided on the under surface of the structural ceiling above. (See fig. 7.)

(1) Cross-furring construction.-This shall consist of crossfurring two or more layers of treated wood strips at right angles as illustrated in figure 4 . The insulation shall be applied in layers between the furring strips. 


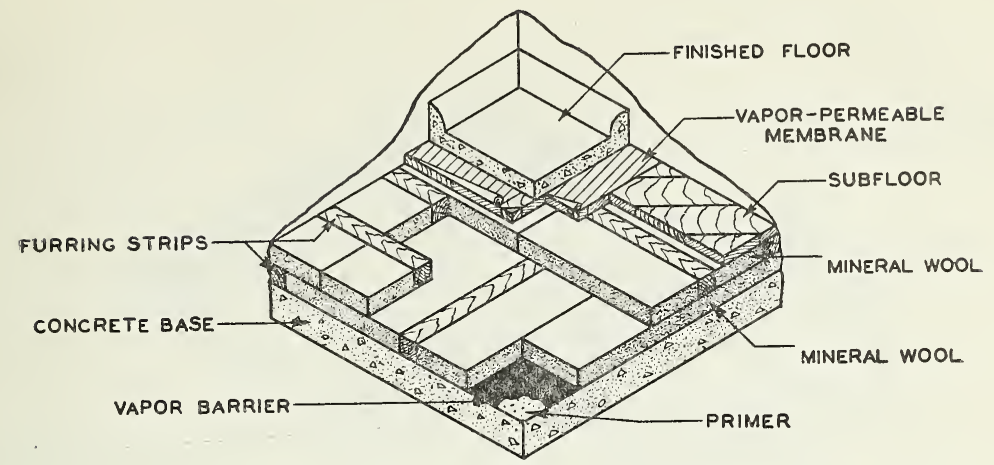

FIGURE 1. Floor-cross-furring construction.

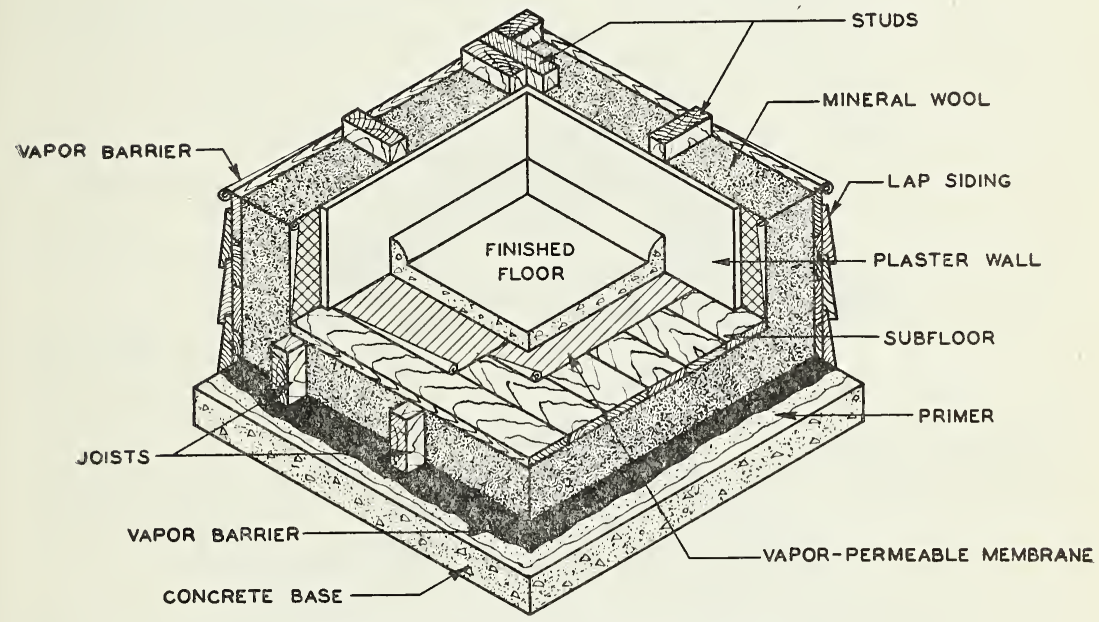

Figure 2. Floor-joist construction.

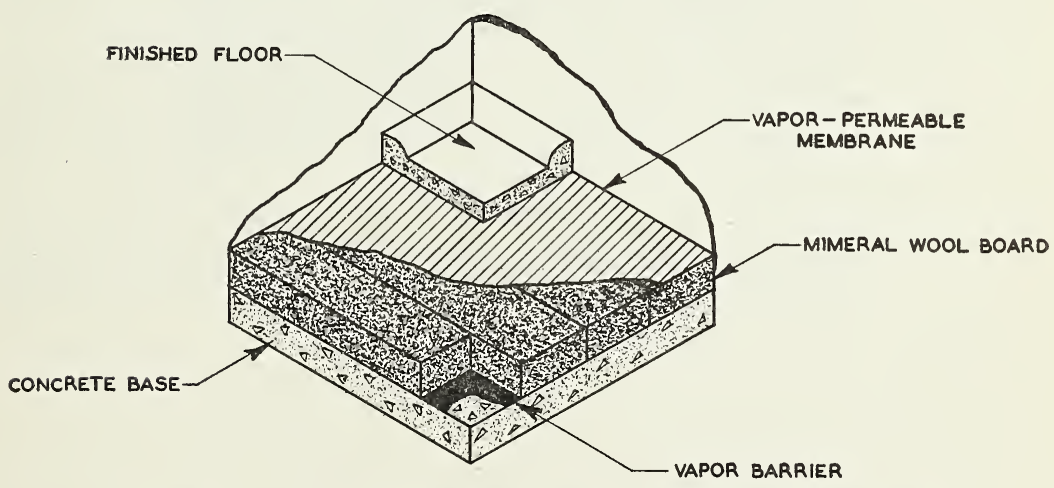

FIGURE 3. Floor-load-carrying mineral wool board construction. $807151-49-2$ 


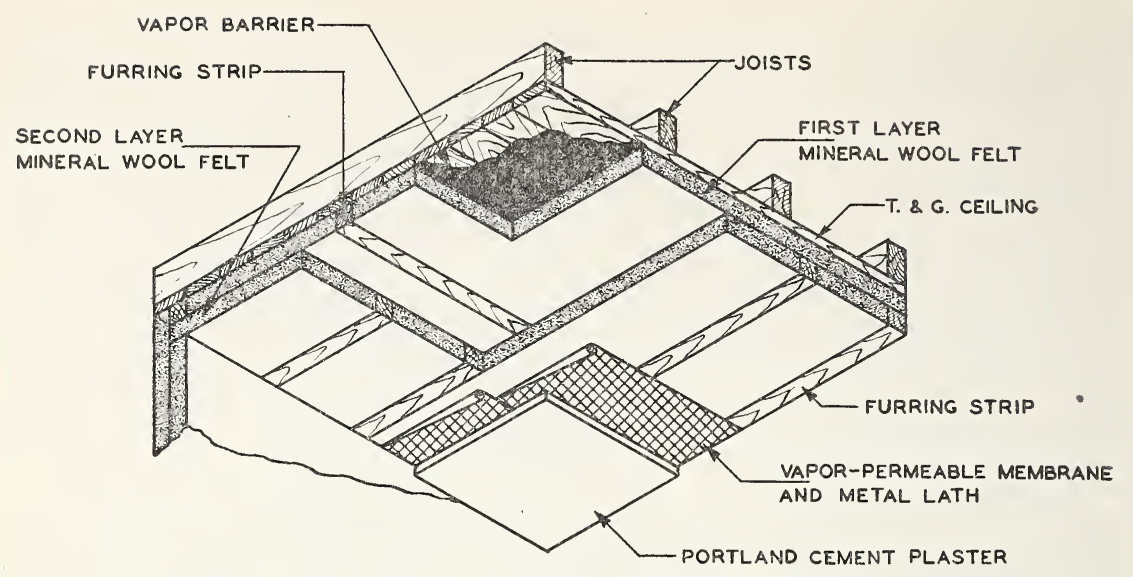

Figure 4. Ceiling-cross-furring construction.

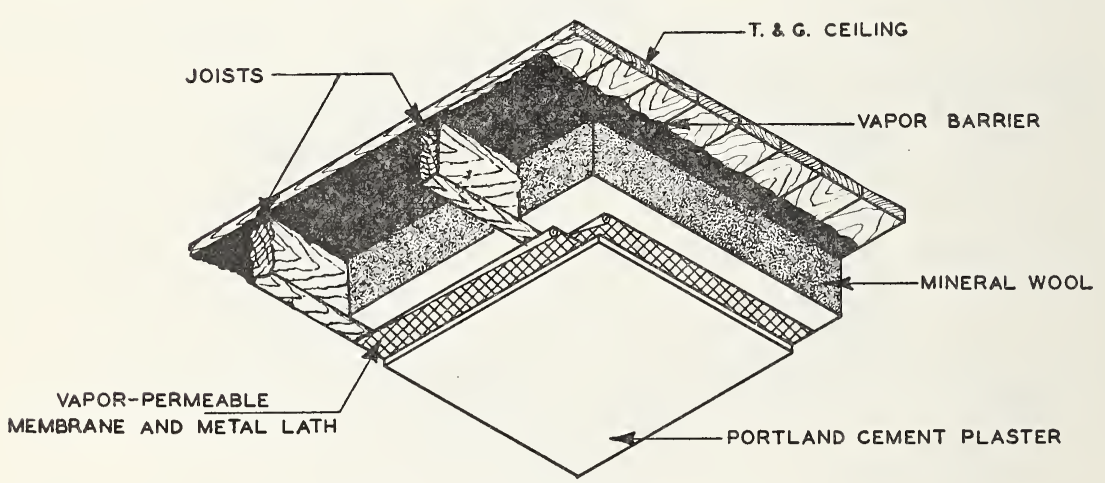

Figure 5. Ceiling-joist construction.

(2) Joist construction.- This shall consist of treated wood joists having a depth equal to the thickness of insulation as illustrated in figure 5. The applied insulation shall completely fill the space between the joists.

(3) Above-ceiling construction.-This shall consist of insulation applied to the desired thickness on the upper side of a structural ceiling as illustrated in figure 6 . The vapor barrier shall be applied on top of the insulation.

(4) Fully suspended construction.-This shall consist of a ceiling of metal lath suspended by hanger rods or wires from the structural members. The insulation is installed as shown in figure 7 . 


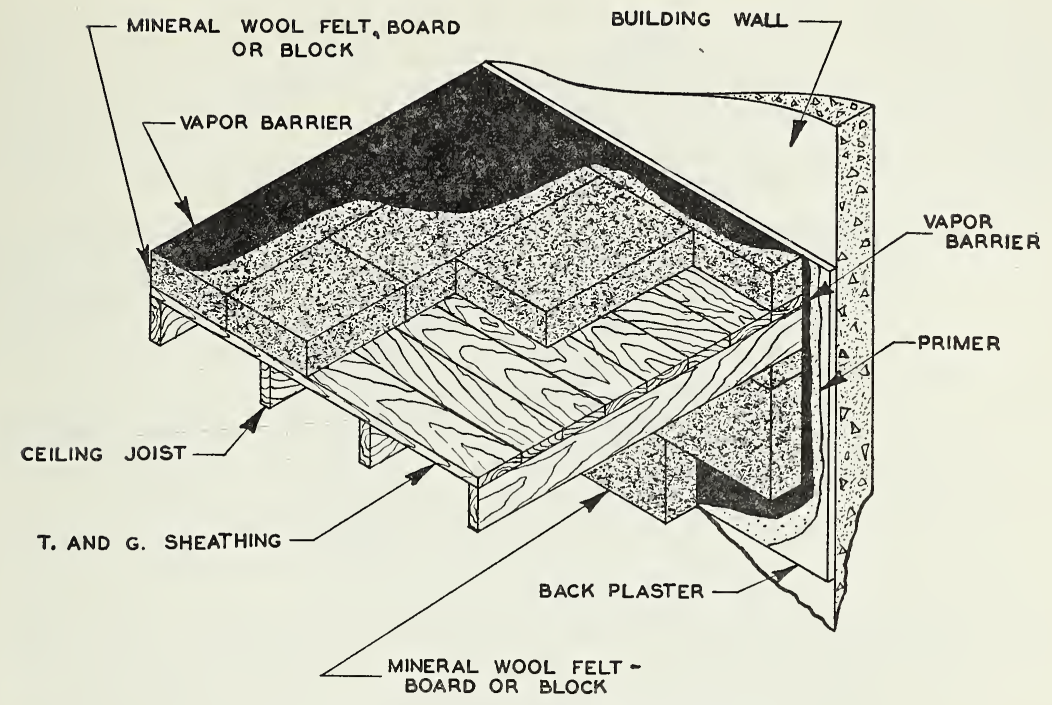

FIgURE 6. Above-ceiling construction.

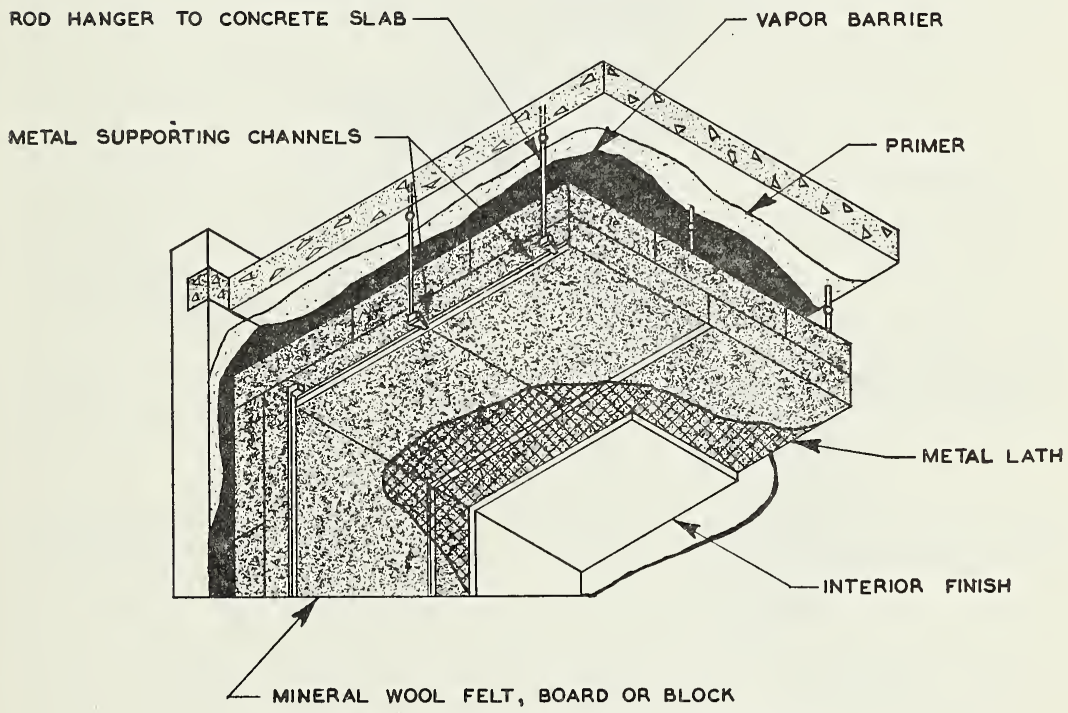

Figure 7. Suspended-ceiling construction. 
11c. Walls.-Before being insulated, the inside surface of exterior walls shall be trued and a vapor barrier applied. Partition walls separating two refriferated spaces shall not be vapor-proofed unless the moisture levels maintained differ widely, or unless one room is operated only periodically. The construction shall be one of the following methods illustrated in figures 8 to 15 inclusive.

(1) Spaced construction.-This construction shall consist of either steel or treated-wood supporting strips of a depth less than the required insulation thickness, and shall be one of the following:

(a) For exterior masonry walls the construction shall be as illustrated by figure 8 .

(b) For exterior or interior wood walls containing included studs on the warm (outer) side, the construction shall be as illustrated by figure 9 .

(c) For interior enclosing wood walls with exposed studs on warm (outer) side, the construction shall be as illustrated in figure 10 .

(2) solid board or block insulation construction.-This shall consist of rigid board or block insulation applied in hot asphalt in one or more layers, with all joints broken.

(a) For exterior or enclosing walls the construction shall be as illustrated in figure 11 .

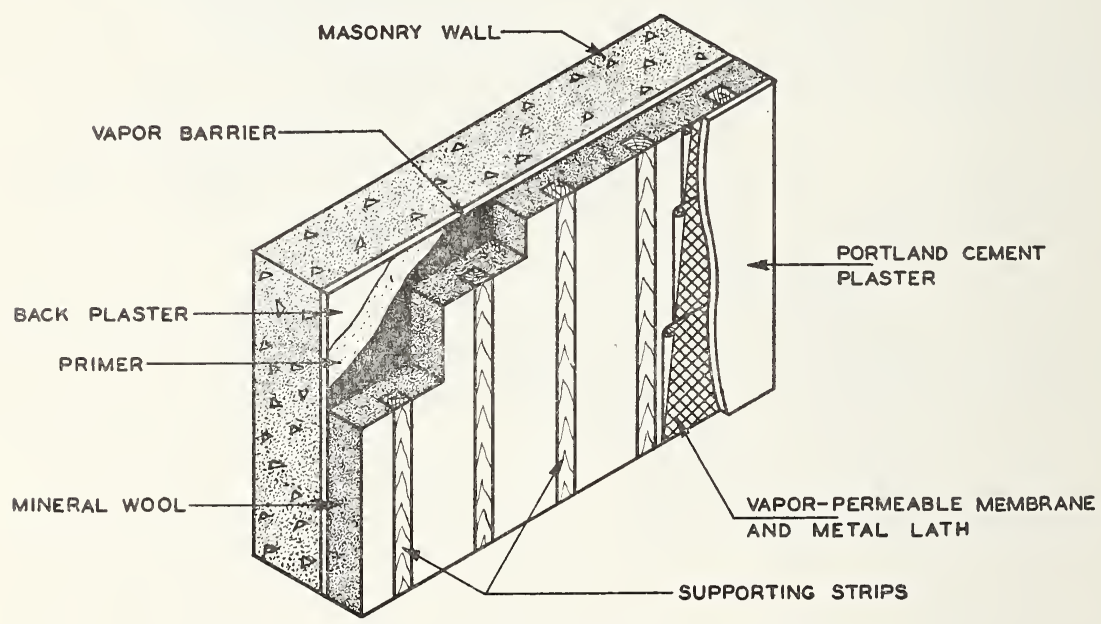

FIGURE 8. Wall-spaced construction-exterior masonry. 


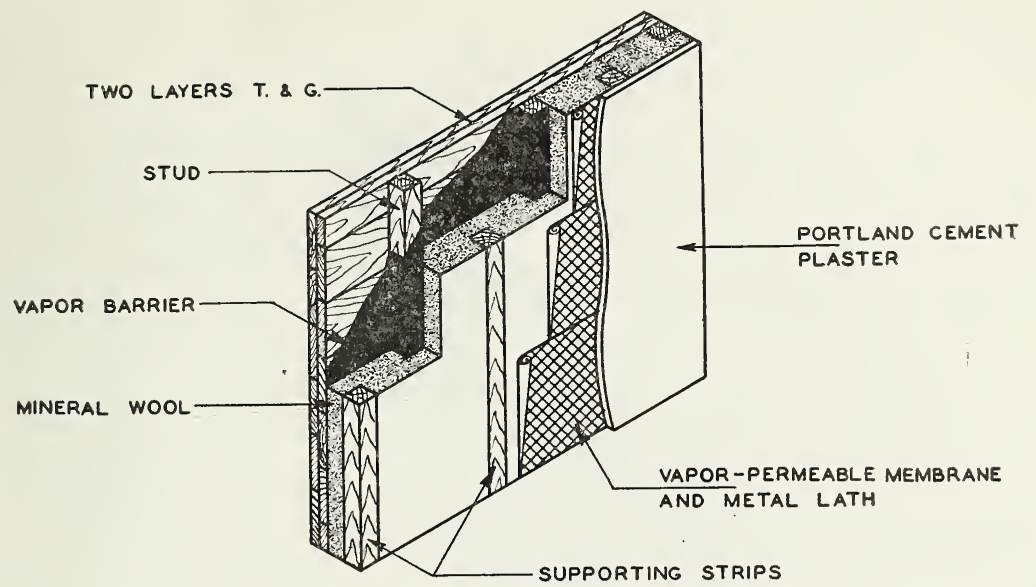

FIGURE 9. Wall-spaced construction-exterior or interior wood, studs not exposed.

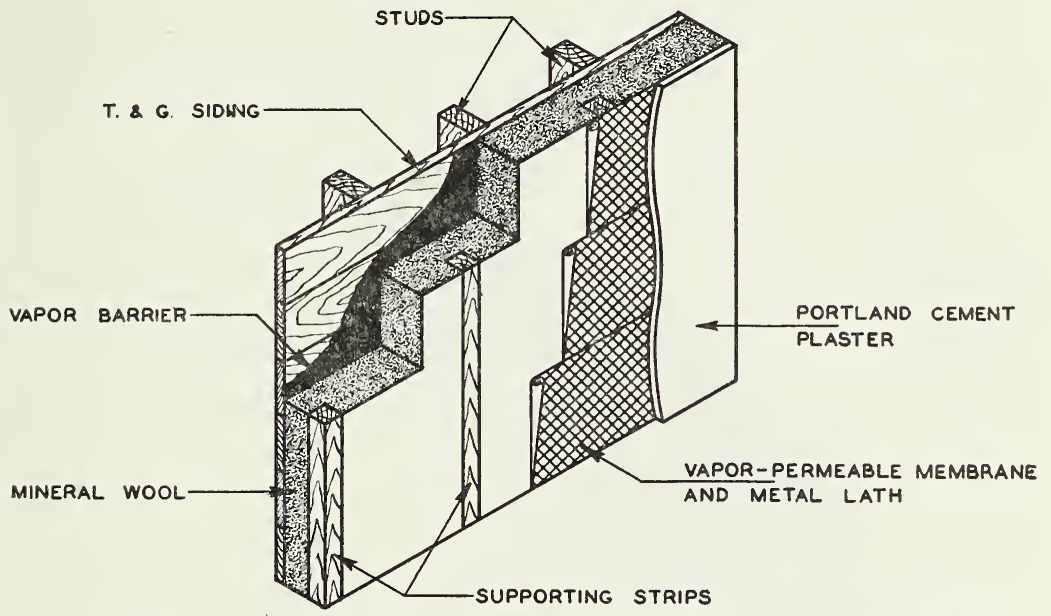

FigURE 10. Wall-spaced construction-interior wood, studs exposed. 


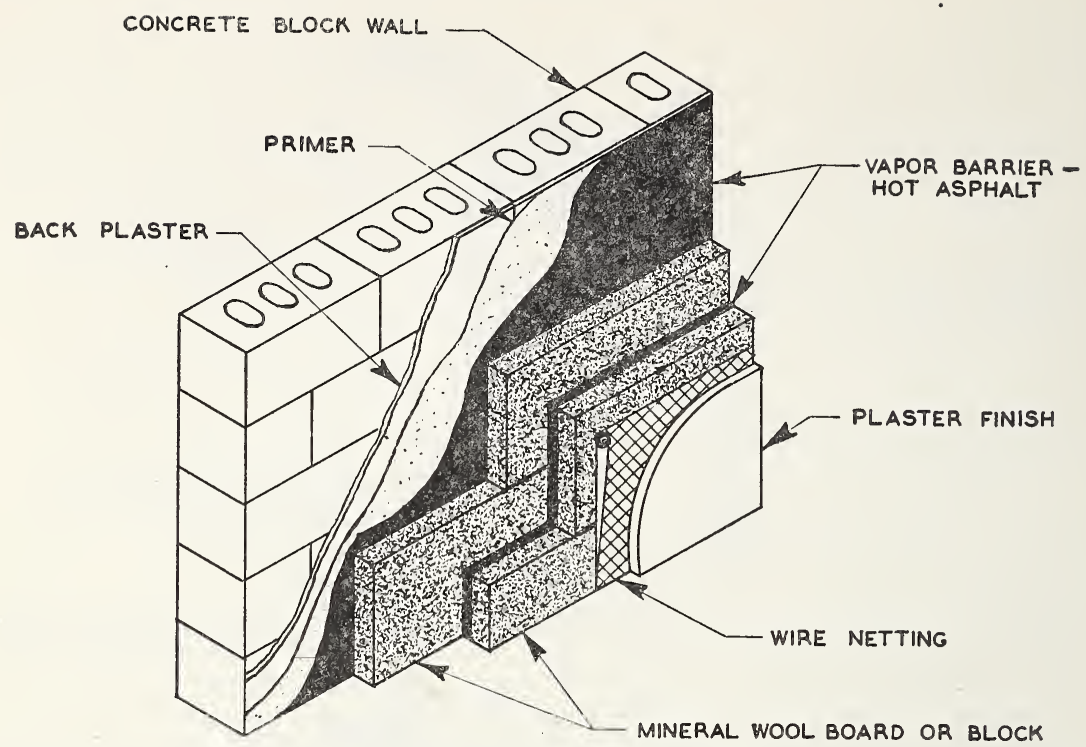

FIgURE 11. Wall-mineral wool board or block construction-exterior or interior masonry.

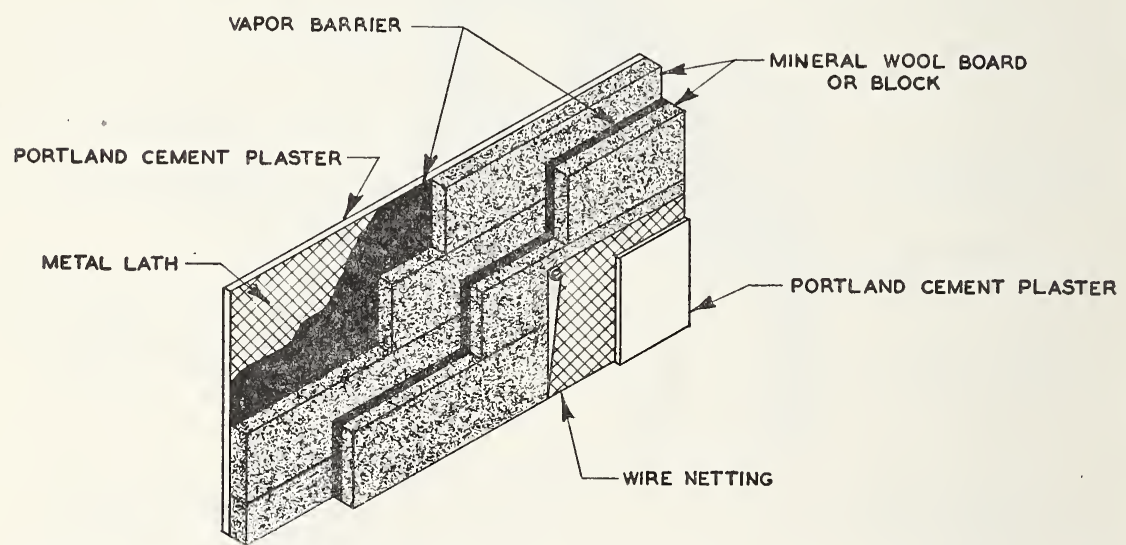

FIgURe 12. Partition wall-mineral wool board or block construction, selfsupporting.

(b) For self-supporting partitions the construction shall be as illustrated in figure 12 . It shall be erected by applying board insulation against a temporary vertical wood partition, which is removed after all layers have been applied.

(3) Stud construction.-This shall consist of mineral wool insulation applied between treated wood studs having a depth equal to the required insulation thickness, as illustrated by figure 13 . 
(4) Cross-furring construction.-This shall consist in crossfurring two or more layers of treated wood strips at right angles, as illustrated by figure 14 .

(5) Double-masonry construction.-This construction shall consist of two self-supporting masonry walls, with the space between completely filled with insulation, as illustrated by figure 15 .

11d. Finish.-The interior finish selected shall be governed by the type of supporting construction employed and the type of service for which the refrigerated space is to be used. The finish and its supports shall be sufficient to protect the insulation from damage due to mechanical abuse, water from cleaning operations, or other effects incidental to normal service. It shall not contain any material or give off vapors or odors detrimental to the products stored. The finish shall be one of the following:

(1) Portland cement plaster.-This shall consist of portland cement, sand, and hydrated lime applied in two coats on metal lath. A vapor-permeable membrane shall be placed between the insulation and the lath. The plaster finish shall be divided into squares of approximately 4 feet on a side, by score-marks almost through the thickness of the plaster.

(2) Asphalt mastic (for board or block insulation).--This shall consist of a mixture of asphalt emulsion, sand, and asbestos fiber applied by troweling over wire netting stapled to the board or block surfaces.

(3) Wood.-This shall consist of wooden sheathing or plywood sheets applied over a vapor-permeable membrane and attached to the supporting construction. The wood species shall be of a type that will not impart objectionable odor or taste to food products stored in the refrigerated space.

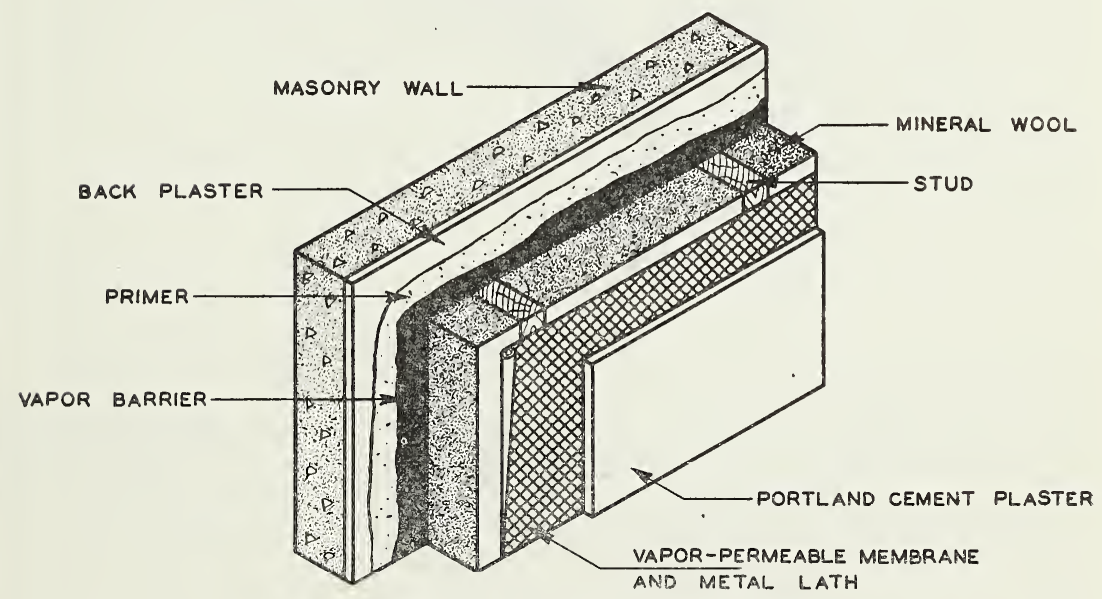

FigURE 13. Wall-stud construction. 


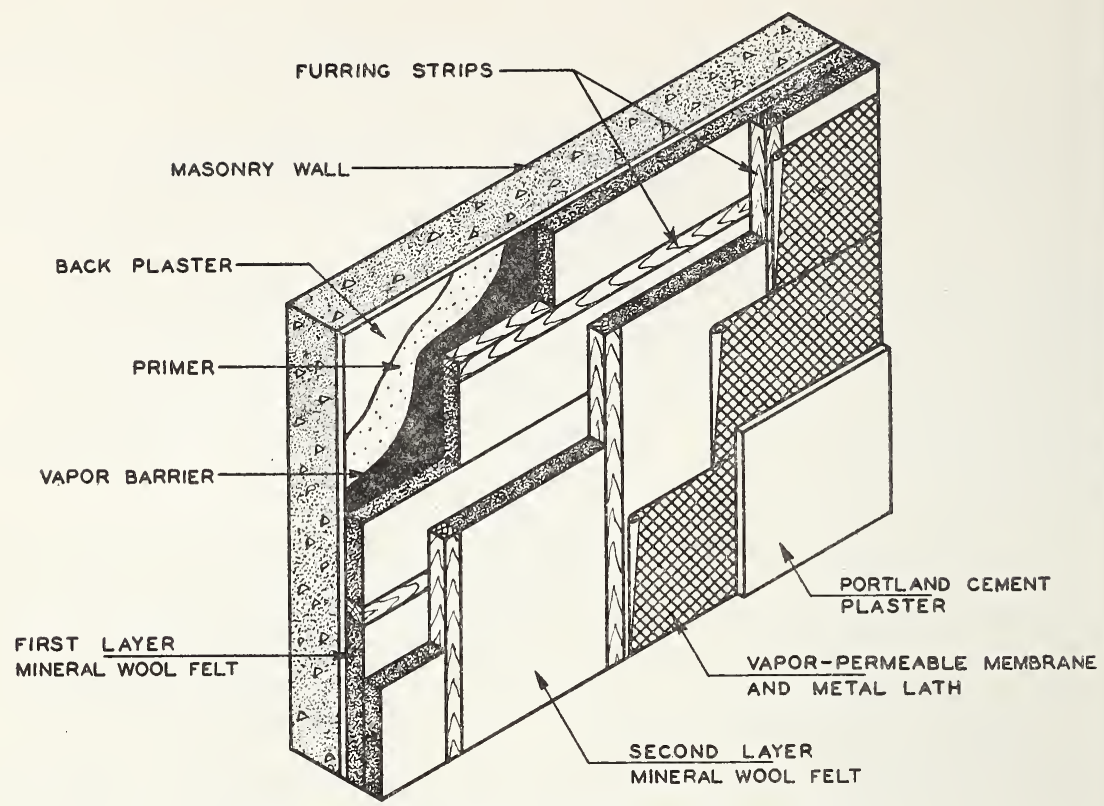

Figure 14. Wall-cross-furring construction.

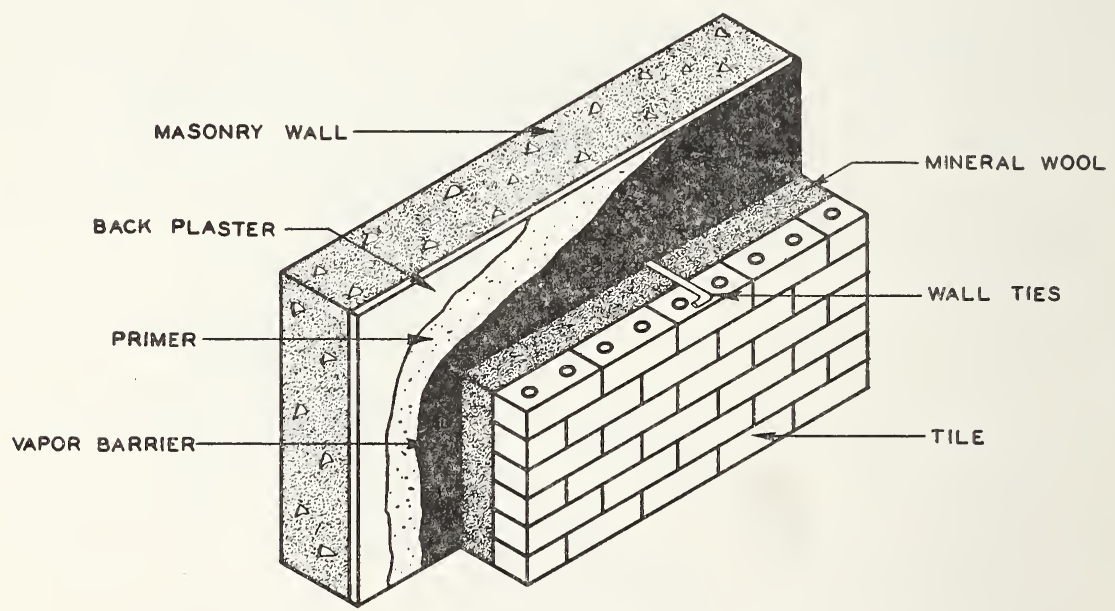

Figure 15. Wall-double-masonry consiruction.

(4) Sheet materials.-These shall consist of manufactured compositions such as s sbestos-cement, wood-fiber board, building board, sheet-metal panels, etc., and shall be selected with reference to the intended service. 


\section{PIPE LINES}

12. Insulation thickness.-Mineral wool insulation on cold pipe lines, valves, and fittings shall be built up to not less than the thicknesses shown in table 3 for specific operating temperatures.

TABLE 3. Minimum built-up thickness of mineral wool for pipe insulation required for various operating temperatures

\begin{tabular}{|c|c|c|c|c|}
\hline \multirow{2}{*}{ Temperature } & \multicolumn{4}{|c|}{$\begin{array}{l}\text { Insulation thickness by ranges of nominal } \\
\text { pipe sizes }\end{array}$} \\
\hline & $\begin{array}{l}\text { 1//4in. } \\
\text { through } \\
11 / 4 \text { in. }\end{array}$ & $\begin{array}{l}11 / 2 \text { in. } \\
\text { through } \\
3 \text { in. }\end{array}$ & $\begin{array}{l}31 / 2 \text { in. } \\
\text { through } \\
5 \text { in. }\end{array}$ & $\underset{\substack{6 \text { in. and } \\
\text { over }}}{ }$ \\
\hline $\begin{array}{l}{ }^{\circ} \mathrm{F} \\
25 \text { to } 45 \\
5 \text { to } 25 \\
-15 \text { to } 5 \\
-45 \text { to }-15\end{array}$ & $\begin{array}{c}\text { Inches } \\
2 \\
2 \\
3 \\
4\end{array}$ & $\begin{array}{c}\text { Inches } \\
3 \\
3 \\
3 \\
3 \\
4\end{array}$ & $\begin{array}{c}\text { Inches } \\
3 \\
3 \\
4 \\
4 \\
5\end{array}$ & $\begin{array}{c}\text { Inches } \\
3 \\
4 \\
5 \\
5\end{array}$ \\
\hline
\end{tabular}

13. Preparation of surface. - All surfaces shall be thoroughly cleaned and dried before insulation is applied, and, once installation has begun, the system shall not be put into operation until the application has been completed. Pipes and other equipment to be insulated shall be relocated, if necessary, to provide an uninterrupted clearance around the finished insulation of at least 4 inches in all directions. Low-temperature pipes shall not be located adjacent to heated surfaces. Pipe covering subjected to abrasion shall be suitably protected.

14. Application of insulation.

14a. Pipes. - The pipe surface to be insulated shall be primed or mopped with hot asphalt or wrapped with a layer of 15-pound saturated rag felt lapped at least 3 inches at all joints. The initial layer of 1-inch felted mineral wool shall then be applied circumferentially around the pipe, securely tying it with jute or similar twine wrapped spirally on 1-inch centers. A layer of 15-pound rag felt shall be mopped with hot asphalt and applied with 3-inch laps over the first layer of insulation. Additional 1-inch thicknesses of felted mineral wool shall then be applied and sealed in a similar manner until built up to the total specified thickness. Over the final layer of felted mineral wool, two layers of 15-pound saturated rag felt shall be applied with 3-inch laps, mopping each layer separately with hot asphalt as shown in figure 16 .

14b. Fittings. - Wherever the pipe is interrupted by fittings, valves, or flanges (and also at every 15 to 20 feet of straight pipe), the pipe insulation shall be carefully sealed off as shown in figure 17. Each layer of felted mineral wool shall be sealed at these points by carrying the 15-pound rag felt down to the previously applied layer of rag felt, not down to the bare pipe in each case. All fittings shall be insulated in the same manner as on adjacent straight piping. Where pipe and fitting insulation meet, the 15-pound rag felt applied on the fitting shall be well sealed to the outer layer of 15-pound rag felt on the pipe insulation. 


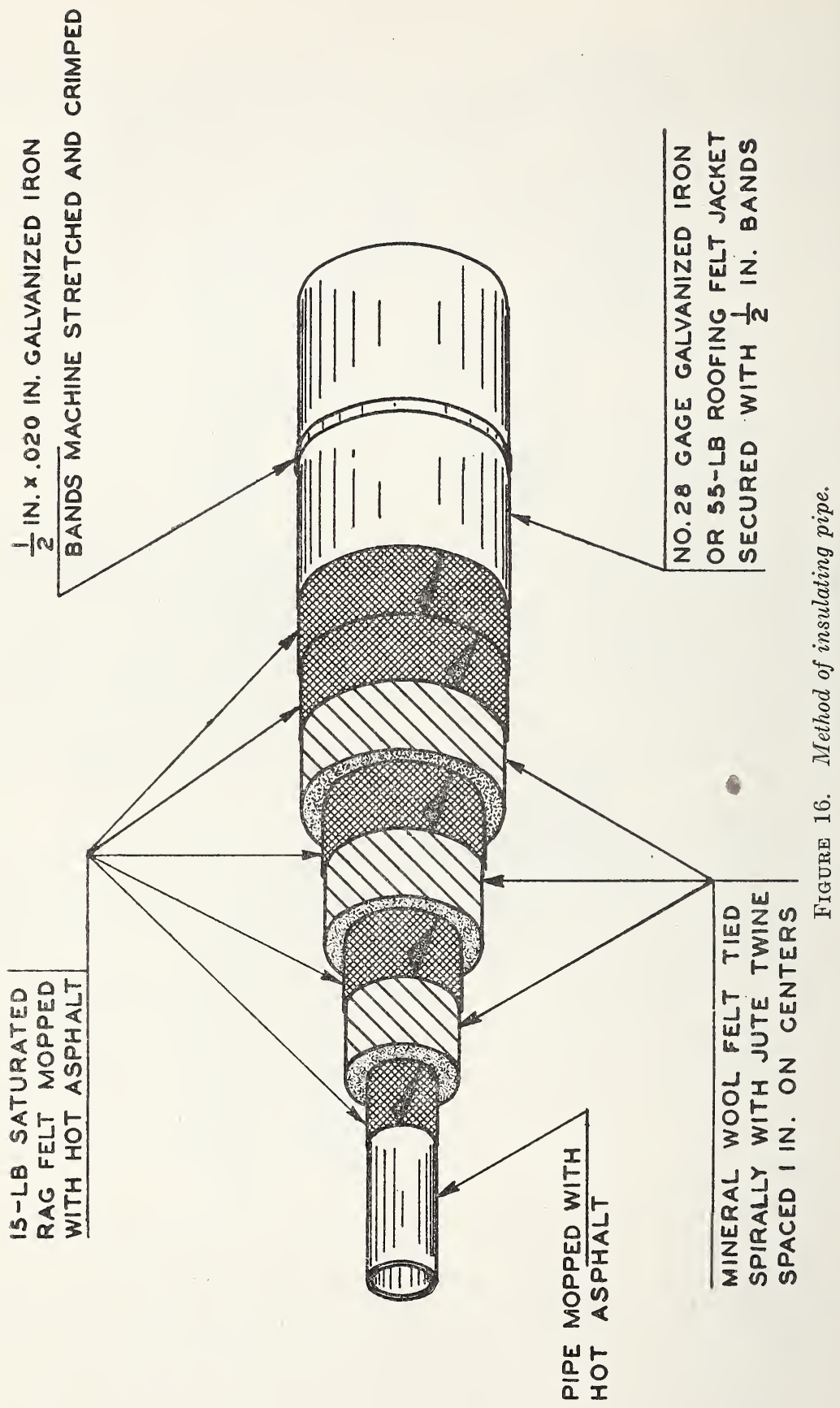




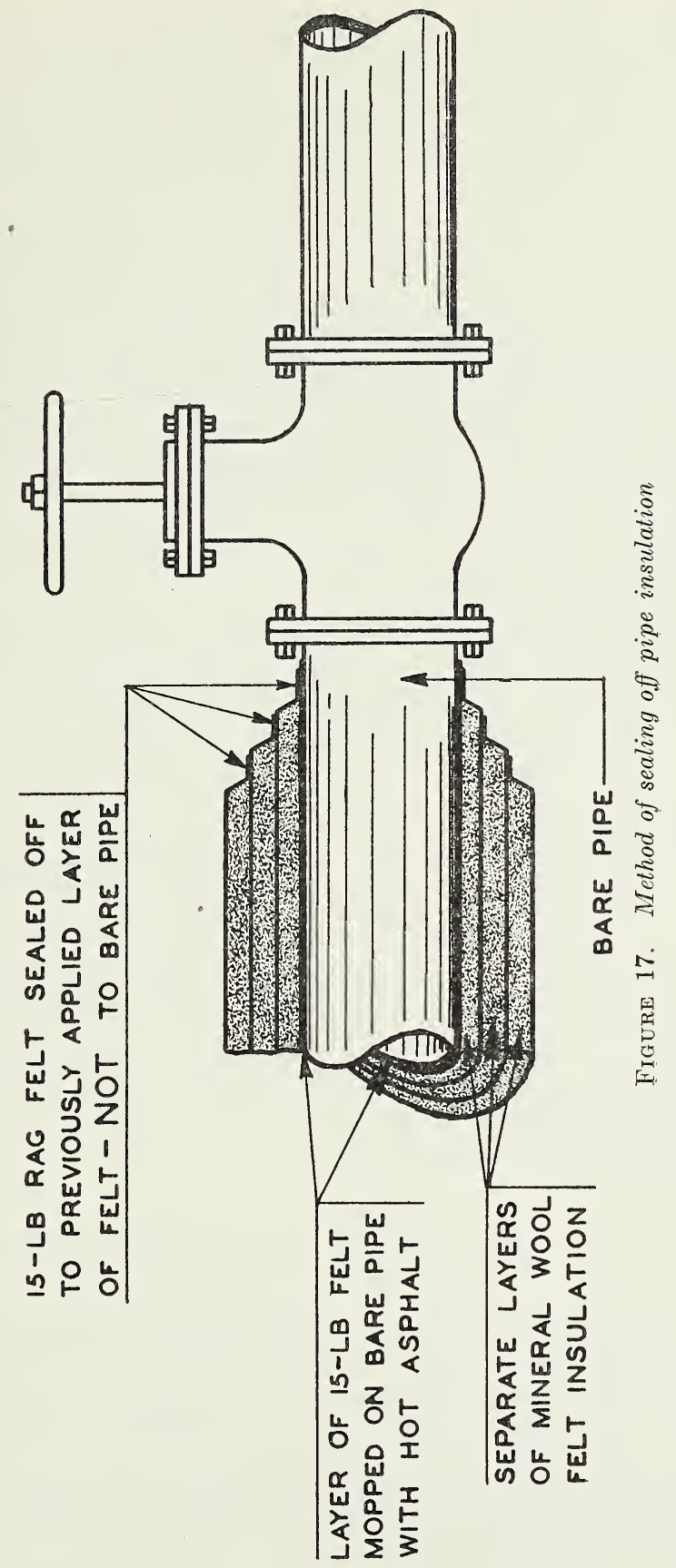


14c. Hangers. - When in direct contact with the pipe, hangers shall be insulated separately and sealed to the pipe insulation; both the insulation and seal shall be applied in a manner similar to the method for fittings. (See par. 14b.) The insulation shall be applied upward along the vertical hanger rod to a point not less than 12 inches from the adjacent pipe insulation.

15. Finish.

15a. Pipe.-After the second outer layer of 15-pound rag felt has been mopped with asphalt and applied, the insulation shall be protected with a jacket of No. 28 gage galvanized sheet metal or with a 55-pound roofing felt. If sheet metal is used, each sheet shall be lapped 3 inches against the weather at all joints and permanently secured in place with 1/2-inch galvanized iron bands spaced on 8-inch to 12-inch centers, machine stretched and crimped. If roofing felt is used as a jacket, all joints shall be lapped as above and the jacket permanently secured in place with $1 / 2$-inch galvanized bands or with copper or soft galvanized wires spaced on 6-inch to 8-inch centers.

15b. Fittings. - All valves, flanges, or other fittings shall be finished by one of the following methods:

(1) A layer of 1-inch galvanized wire-mesh netting shall be tightly stretched over the final layer of 15-pound rag felt and secured in place with No. 18 gage wire. Emulsified asphalt weatherproofing shall then be applied at the rate of 2 pounds per square foot of area (approximately $1 / 4$ inch thick, wet), troweling it well into the wire-mesh netting.

(2) A layer of rosin-sized sheathing paper shall be applied over the final layer of 15-pound rag felt, lapping it 3 inches at all joints and sealing the laps with asphalt. A jacket of 8-ounce canvas shall then be sewed or pasted over the rosin-sized paper. If sewed, the stitches shall be spaced not less than three to the inch, located where least visible.

16. Painting.-When specified, insulation finished with weatherproofing shall be painted with aluminum or asphalt-base paint; insulation finished with 8-ounce canvas shall be given a coat of glue sizing followed by two coats of white lead in oil, tinted to color selected by the purchaser.

\section{GUARANTEE LABELS AND CERTIFICATES}

17. Manufacturers' labels.-In order to assure the purchaser that he is receiving mineral wool that will comply with the requirements of this commercial standard, it is recommended that manufacturers, individually or in concert with their trade association, issue guarantee labels. The following wording is recommended for such labels:

This mineral wool is declared to conform to the requirements of Commercial Standard CS105-48, as developed by the trade, under the procedure of the National Bureau of Standards and issued by the U. S. Department of Commerce. 1 
18. Contractor's certificate.-In order to be assured that the mineral wool insulation is properly installed, it is further recommended that the contractor be required to furnish a certificate that the supporting construction of the insulation has been erected and the installation of the insulating material has been made in accordance with this standard. The following wording is recommended for the certificate, which should be attached in a conspicuous place on the door or wall of the insulated area:

In this refrigerated area, supporting construction has been erected and certified mineral wool insulation has been installed in accordance with the requirements of Commercial Standard CS105-48, as developed by the trade under the procedure of the National Bureau of Standards, and issued by the U. S. Department of Commerce.

This refrigerated area has been designed for a minimum operating temperature of .... ${ }^{\circ} \mathrm{F}$ and _............ type(s) of mineral wool insulation has (have) been installed.

Date

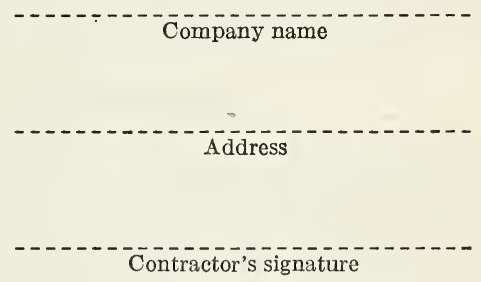

\section{EFFECTIVE DATE}

19. Having been passed through the regular procedure of the Commodity Standards Division, and approved by the acceptors hereinafter listed, this commercial standard was issued by the United States Department of Commerce, effective from October 20, 1948.

EDwIN W. ELY, Chief, Commodity Standards Division.

\section{HISTORY OF PROJECT}

On April 28, 1942, the Industrial Mineral Wool Institute requested the cooperation of the National Bureau of Standards in the establishment of a commercial standard for mineral wool, in the loose, granulated, and felted form, and its installation in insulating low-temperature areas. A draft of the proposed commercial standard was submitted on August 11, 1942, to manufacturers of mineral wool, and their comment considered at a meeting held at Cleveland, Ohio, on September 18, 1942. An adjusted draft was then prepared and submitted on October 1, 1942, to manufacturers and to technical, distributor, and consumer organizations for review and comment. The standard was then modified in accordance with the composite recommendations of 
those concerned and circulated on December 8, 1942, to the trade for written acceptance.

Upon receipt of acceptances estimated to represent a satisfactory majority, the standard was promulgated as Commercial Standard CS105-43, effective for new production from March 1, 1943.

\section{FIRST REVISION}

Pursuant to a request from the Industrial Mineral Wool Institute, dated August 6, 1947, and following approval by the standing committee, a recommended revision was circulated to the trade for their consideration on July 14, 1948. The major change in the revision was the inclusion of mineral wool boards and blocks, together with five descriptive illustrations showing construction methods for using these types of installations. In addition to these, requirements for moisture sorption, corrosive properties, odor, fire resistance, cold asphalt mastic, asphalt emulsion, and reenforcing membranes are now contained in the standard. Following acceptance by a satisfactory majority, the establishment of the revision was announced on September 20, 1948, as Commercial Standard CS105-48, effective for new production from October 20, 1948.

\section{STANDING COMMITTEE}

The following individuals comprise the membership of the standing committee, which is to review, prior to circulation for acceptance, revisions proposed to keep the standard abreast of progress. Comment concerning the standard and suggestions for revision may be addressed to any member of the committee or to the Commodity Standards Division, National Bureau of Standards, which acts as secretary for the committee.

K. M. Ritchie (chairman), Baldwin-Hill Co., 500 Breunig Avenue, Trenton 2, N. J.

D. W. Burnetr, National Gypsum Co., Alexandria, Ind.

H. E. Lewis, The Eagle-Picher Sales Co., American Bldg., Cincinnati 1, Ohio.

C. A. Smucker, Owens-Corning Fiberglas Corp., Newark, Ohio.

George K. Bentuy, McCray Refrigerator Co., Kendallville, Ind. (Representing Commercial Refrigerator Manufacturers Association.)

J. W. Strohman, Public Buildings Administration, Federal Works Agency, Washington 25, D. C.

T. A. D. Jones, Kingan \& Co., Indianapolis, Ind. (Representing American Meat Institute.)

E. M. Burns, Northwest Frozen Foods Association, 507 Board of Trade Bldg., Portland, Oreg.

James C. Irwin, United States Cold Storage Co., 500 E. Third Street, Kansas City, Mo. (Representing National Association of Refrigerated Warehouses.)

C. P. Austin, National Association of Ice Industries, 1706 L Street NW, Washington $6, \mathrm{D} . \mathrm{C}$. 


\section{ACCEPTANCE OF COMMERCIAL STANDARD}

If acceptance has not previously been filed, this sheet properly filled in, signed, and returned will provide for the recording of your organization as an acceptor of this commercial standard.

\section{Date}

Commodity Standards Division,

National Bureau of Standards, Washington 25, D. C.

\section{Gentlemen:}

We believe that the Commercial Standard CS105-48 constitutes a useful standard of practice, and we individually plan to utilize it as far as practicable in the

production $^{1} \quad$ distribution $^{1} \quad$ purchase $^{1} \quad$ testing $^{1}$

of mineral wool insulation for low temperatures.

We reserve the right to depart from it as we deem advisable.

We understand, of course, that only those articles which actually comply with the standard in all respects can be identified or labeled as conforming thereto.

Signature of authorized officer

\section{(In ink)}

(Kindly typewrite or print the following lines)

Name and title of above officer.

Organization

(Fill in exactly as it should be listed)

Street address

City, zone, and State

1 Underscore which one. Please see that separate acceptances are filed for all subsidiary companies and affiliates which should be listed separately as acceptors. In the case of related interests, trade associations, trade papers, etc., desiring.to record their general support, the words "General Support" should be added after the signature. 


\section{TO THE ACCEPTOR}

The following statements answer the usual questions arising in connection with the acceptance and its significance:

1. Enforcement.-Commercial standards are commodity specifications voluntarily established by mutual consent of those concerned. They present a common basis of understanding between the producer, distributor, and consumer and should not be confused with any plan of governmental regulation or control. The United States Department of Commerce has no regulatory power in the enforcement of their provisions; but since they represent the will of the interested groups as a whole, their provisions through usage soon become established as trade customs and are made effective through incorporation into sales contracts by means of labels, invoices, and the like.

2. The acceptor's responsibility. - The purpose of commercial standards is to establish, for specific commodities, nationally recognized grades or consumer criteria, and the benefits therefrom will be measurable in direct proportion to their general recognition and actual use. Instances will occur when it may be necessary to deviate from the standard, and the signing of an acceptance does not preclude such departures; however, such signature indicates an intention to follow the commercial standard where practicable, in the production, distribution, or consumption of the article in question.

3. The Department's responsibility.-The major function performed by the Department of Commerce in the voluntary establishment of commercial standards on a Nation-wide basis is fourfold: first, to act as an unbiased coordinator to bring all interested parties together for the mutually satisfactory adjustment of trade standards; second, to supply such assistance and advice as past experience with similar programs may suggest; third, to canvass and record the extent of acceptance and adherence to the standard on the part of producers, distributors, and users; and fourth, after acceptance, to publish and promulgate the standard for the information and guidance of buyers an sellers of the commodity.

4. Announcement and promulgation.-When the standard has been endorsed by a satisfactory majority of production or consumption in the absence of active, valid opposition, the success of the project is announced. If, however, in the opinion of the standing committee or the Department of Commerce, the support of any standard is inadequate, the right is reserved to withhold promulgation and publication. 


\section{ACCEPTORS}

The organizations listed below have individually accepted this standard for use as far as practicable in the production, distribution, testing, or purchase of mineral wool insulation for low-temperature installations. In accepting the standard they reserved the right to depart therefrom as they individually deem advisable. It is expected that products which actually comply with the requirements of this standard in all respects will be regularly identified or labeled as conforming thereto, and that purchasers will require such specific evidence of conformity.

\section{ASSOCIATIONS}

(General Support)

American Institute of Architects, Kansas City Chapter, Kansas City, Mo.

American Specification Institute, Chicago, Ill.

Carolina Lumber \& Building Supply Association, Inc., Charlotte, N. C.

Industrial Mineral Wool Institute, New York, N.Y. Michigan Retail Lumber Dealers Association, Lansing, Michigan.

Prefabricated Home Manufacturers' Institute, Washington, D. C.

Southern California Retail Lumber Association, Los Angeles, Calif.

United Roofing Contractors' Association, Chicago, Ill.

\section{FIRM̊S AND OTHER INTERESTS}

Ackerman, Frederick L., New York, N. Y. Adams, Franklin O., Tampa, Fla.

Advanced Refrigeration, Inc., Atlanta, Ga.

Altfillisch, Charles, Decorah, Iowa.

Alton Mineral Wool Insulation Co., St. Louis, Mo. American Ice Co., New York, N. Y'.

American Packing \& Provision Co., Ogden, Utah. American Rock Wool Corp., Chicago, Ill.

American Ship Building Co., The, Cleveland, Ohio. American Standards Testing Bureau, Inc., New York, N. Y.

Andrews, Jones. Biscoe \& Goodell, Boston, Mass.

Arbogast \& Bastian, Inc., Allentown, $\mathrm{Pa}$.

Armor Insulating Co., Atlanta, Ga.

Atlantic States Warehouse \& Cold Storage Corp. Springfield, Mass.

A VCO Manufacturing Corp., Crosley Division, Cincinnati, Ohio.

Avondale Marine Ways, Inc., Westwego, La.

Baldwin-Hill Co., Trenton, N. J.

Baxter, C. B., \& Co., Kansas City, Mo.

Beeson, Carroll O., Crawfordsville, Ind.

Belli, Edo J., Chicago, $\mathrm{nl}$.

Beuttler, William, Sioux City, Iowa.

Binda, Bial \& Gerhardt, Union City, N. J.

Bishop, Horatio W., La Mesa, Calif.' (Genera! support.)

Boehm, George A., New York, N. Y.

Boukind, P. P., Anaconda, Mont.

Bovard, William R., Kansas City, Mo. (General support.)

Bow ser-Morner Testing Laboratorics, Dayton, Ohio Brazer, Clarence W., New York, N. Y.

Brizzolara, Robert T., New York, N. Y.

Brooks-Borg, Des Moines, Iowa.

Brust \& Brust, Milwaukee, Wis.

Bucky, Fred W., Jr., Jacksonville, Fla.

Cabot Carbon Co., Retort Chemical Division, Gainesville, Fla.

California Consumers Corp., Los Angeles, Calif.

California 'Testing Laboratories, Inc., Los Angeles, Calif.

Cameron, Wm., \& Co., Inc., Waco, Tex,

Cameron Lumber Co., Inc., Newburgh, N. Y.
Camlet, J. Thomas, Passaic, N. J.

Campbell Rock Wool Co., Salem, Oreg.

Cannon \& Mullen, Salt Lake City, Utah.

Carey, Philip, Manufacturing Co., The, Lockland, Cincinnati, Ohio.

Carney Co., Inc., The, Minneapolis, Minn., and Mankato, Minn.

Cellarius, Chas. F., Cincinnati, Ohio.

Chapin, Rollin C., Minneapolis, Minn. (General support.)

Chapin Lumber Co., The, Aurora, Colo.

Charlottesville Lumber Co., Inc., The, Charlottesville, Va.

Chrysler Corp., A ir temp Division, Dayton, Ohio.

Cincinnati Butchers Supply Co., The, Cincinnati, Ohio.

Colorado Insulating Co., Denver, Colo.

Coolidge, Shepley, Bulfinch \& Abbott, Boston, Mass.

Corson, G. \& W. H., Inc., Plymouth Meeting, Pa. Cram \& Ferguson, Boston, Mass,

Crowell \& Lancaster, Bangor, Maine.

Darby, Bogner \& Associates, Milwaukee, Wis .

DeJarnette, Charles Wagner, Des Moines, Iowa (General support.)

Detroit, City of, City Engineer's Office, Detroit, Mich.

Dietel, Geo. J., Buffalo, N. Y

Eagle-Picher Sales Co., The, Cincinnati, Ohio.

Elektrokemisk, A. S., New York, N. Y

English, Miller \& Hockett, Inc., Hutchinson, Kans.

Evans Products Co., Plymouth, Mich.

Everett, H. F., \& Associates, Allentown, Pa.

Federal Building Material Co., Tulsa, Okla.

Federal Portland Cement Co., Inc., The, Buffalo, N. Y.

Fellheimer \& Wagner, New York, N. Y.

Feltrok Insulation Manufacturing Co., Tacoma, Wash.

Flakice Corp., Brooklyn, N. Y.

Flannigan, Eric G., Henderson, N. C.

Fogel Refrigerator Co., Philadelphia, $\mathrm{Pa}$.

Froelich Air Conditioning \& Sheet Metal Shop, Junction City, Kans.

Furer, Wm. C., Honolulu, T. H.

Gartner Refrigeration Co., Duluth, Minn.

General Ice Cream Corp., Erie, $\mathrm{Pa}$.

General Millwork Corp., Utica, N. Y.

Giesler Home Conditioning, Kearney, Nebr.

Glassboro Cold Storage Corp., Glassboro, N. J.

Green's Ready-Built Homes, Inc., Rockford, ill.

Gypsum Lime \& Alabastine, Canada, Ltd., Toronto, Ont., Canada.

Hahn, Stanley W., Chicago, $\mathrm{Il}$

Haralson \& Mott, Fort Smith, Ark.

Harley, Ellington \& Day, Inc., Detroit, Mich.

Harris Laboratories, Lincoln, Nebr.

Haxby, Bissell \& Belair, Minneapolis, Minn.

Helfensteller, Hirsh \& Watson, St. Louis, Mo.

Herron, James H., Co., The, Cleveland, Ohio.

Higgins, Charles H., New York, N. Y.

Hinckley, John, \& Son Co., Hyannis, Mass.

Hofimann Lumber Co., Pittsburgh, Pa.

Holmes Foundry Co., Ltd., Sarnia, Ontario, Canada. 
Houkom, S. M., Fargo, N. Dak

Houston Laboratories, Houston, Tex.

Houston Packing Co., Houston, Tex.

Hutchings, E. T., Louisville, Ky.

Idaho, University of, Materials Testing Laboratory,

College of Engineering, Moscow, Idaho.

Ideal Dri Ice Manufacturing Co., Ada, Okla.

Illinois Central Railroad, Chicago, Ill.

Industrial Products Co., Nashville, Tenn.

Insulation Products, Ltd., Toronto and Hamilton, Ontario, Canada.

Insulations, Inc., Salt Lake City, Utah.

Intercontinental Packers, Ltd., Saskatoon, Sask. Canada.

Ivey, Edwin J., Inc., Seattle, Wash.

Kansas State College, Department of Architecture, Manhattan, Kans.

Keich \& O’Brien, Warren, Ohio.

Ketchikan Cold Storage Co., Ketchikan, Alaska.

Kingan \& Co., Inc., Indianapolis, Ind.

Krueger, G., Brewing Co., Newark, N. J.

Kyle, Herbert S., Charleston, W. Va. (General support.)

Law, Law, Potter \& Nystrom, Madison, Wis.

Lee, W. H., Philadelphia, Pa.

Levine, Ernest, New Brunswick, N. J.

Levy, Will, St. Louis, Mo.

Lingo Lumber Co., Dallas, Tex.

Lucht, Harry Allan, West Englewood, N. J.

Lul Products, Inc.-U. S. A., Baltimore, Md

Lundgren Dealers Supply, Inc., Tacoma, Wash.

Maine Home Insulation Co., Inc., Portland, Maine.

Manitowoc Refrigerating Co., Manitowoc, Wis.

Marshall-Wright Lumber Co., Inc., Ionia, Mich.

Martin, Edgar, Chicago, Ill.

Mason, George D., \& Co., Detroit, Mich.

McCabe \& White Co., Providence, R. I.

Merrill-Schaaf Lumber Co., Pierre, S. Dak.

Michigan Wholesalers, Inc., Jackson, Mich.

Mid-West Lumber Co., Mankato, Kans.

Midwest Lumber Co., Dubuque, Iowa.

Miller \& Vrydagh, Terre Haute, Ind.

Mineral Wool \& Building Guard Manufacturing

Co., Inc., Memphis, Tenn.

Minnesota Testing Laboratories, Inc., Duluth, Minn.

Moore Dry Dock Co.,-Oakland, Calif.

Mooser, William, San Francisco, Calif.

Morell, N. L., Bethlehem, Pa.

Mueller, Hair \& Hetterich, Hamilton, Ohio.

Muhlenberg Bros., Reading, Pa.

Mutual Ice \& Cold Storage Co., The, Topeka, Kans

National Gypsum Co., Buffalo, N. Y.

National Korectaire Co., Chicago, Ill.

National Locker Plants, Des Moines, Iowa.

National Rock Wool Sales, Inc., Lagro, Ind.

New Hampshire Highw ay Department Laboratory, Concord, N. H.

New York Testing Laboratories, Inc., New York, N. Y.

Norfolk Testing Laboratories, Norfolk, Va.

Northern Pacific Railway Co., St. Paul, Minn.

O \& N Lumber Co., Menomonie, Wis.

Officer, Gwynn, Lafayette, Calif.

Oklahoma A \& M College, stillwater, Okla.

Oregon State College, Mechanical Engineering Department, Corvallis, Oreg.

Orthmann Laboratories, Inc., The, Milwaukee, Wis.

Owens-Corning Fiberglas Corp., Toledo, Ohio.

Pabst Air Conditioning Corp., Long Island City, N. Y.

Pacific Refrigerating Co., Tacoma, Wash.

Pease Woodwork Co. Inc., Cincinnati, Ohio.

Pelican Ice \& Cold Storage, Inc., New Orleans, La. (General support.)

Pendleton Terminal Corp., New Crleans, La.

Pennant Insulation Co., Parsons, Kans.

Pepper, George W., Jr., Philadelphia, Pa.

Perfect Seal Rock Wool Manufacturing Co., Walworth, Wis.

Pevely Dairy Co., St. Louis, Mo.

Pictsweet Foods, Inc., Mount Vernon, Wash.

Pittsburgh Case Sales Co., Pittsburgh, $\mathrm{Pa}$.

Pittsburgh Corning Corp., Pittsburgh, Pa.

Pittsburgh Testing Laboratory, Pittsburgh, $\mathrm{Pa}$.

Platt, F. P., \& Bro., New York, N. Y.

Poe, C. W., Co., The, Cleveland, Ohio.

Postler, John, Cincinnati, Ohio. (General support.)
Purdy, W. S., Co., Inc., Brooklyn, N. Y.

Refrigeration Economics Co., Inc., Canton, Ohio.

Rensselaer Polytechnic Institute, Troy, N. Y.

Resnikoff, A braham, New York, N. Y.

Richardson-Phelps Lumber Co., Grinnell, Iowa. Risser, Art, Lumber \& Manufacturing Co., Paris, Ill. Ritchie, James H., \& Associates, Boston, Mass.

Riverton Lime \& Stone Co., Inc., Riverton, Va.

Robert \& Co. Associates, Inc., Atlanta, Ga.

Robinson, Louis G., Laboratories, Cincinnati, Ohio. Rolfe Building Materials Co., New Brunswick, N.J. Russell, Crowell, Mullgardt \& Schwarz, St. Louis, Mo.

Sadtler, Samuel P., \& Son, Inc., Philadelphia, Pa. Salem Lime \& Stone Co., Salem, Ind.

Seeger Refrigerator Co., St. Paul, Minn.

Servel, Inc., New York, N. Y.

Shaver, Charles W. \& John A., Salina, Kans.

Shilstone Testing Laboratory, Inc., New Orleans, La.

Sidells, The Office of Arthur F., Warren, Ohio.

Sirrine, J. E., Co., Greenville, S. C.

Skinner \& Sherman, Inc., Boston, Mass.

Smith, Hinchman \& Grylls, Inc., Detroit, Mich.

Smith-Sharpe Co., Minneapolis, Minn.

Southern Testing Laboratories, Inc., Birmingham, Ala.

Specification Record, Chicago, "Ill.

Springer, B. F., Supply Co., Milwaukee, Wis.

Spun Rock Wools, Ltd., Thorold, Ont., Canada.

Standard Lime \& Stone Co., The, Baltimore, Md.

Standard Lumber Co., Spokane, Wash.

Staub \& Rather, Houston, Tex.

Stewart, A. P., Lumber Co., Thermopolis, Wyo.

Stoetzel, Ralph, Chicago, Ill

Stokes \& Allyn, Portland, Oreg.

Stravs, Carl B., Minneapolis, Minn

Streeter, Daniel D., Brooklyn, N. Y.

Summers Lumber \& Supply Corp., Bay Shore, N. Y.

Sun Oil Co., Philadelphia, $\mathrm{Pa}$

Sweet's Catalog Service, New York, N. Y. (General support)

Taylor, Ellery Kirke, Haddonfield, N. J.

Taylor, Ellis Wing, Los Angeles, Calif.

Temple, Seth J.-Arthur Temple, Davenport, Iowa.

Texas \& Pacific Railway Co., The, Dallas, Tex.

Tex-Rock Insulation Manufacturing Co., Temple, Tex.

Therm-O-Proof Insulation Manufacturing Co., Chicago, III.

Thomas Air Conditioning, Inc., Norfolk, Va.

Thompsen \& Lichtner Co., Inc., The, Brookline, Mass.

Thorne, Henry Calder, Ithaca, N. Y

Tobin Packing Co., The, Albany Division, Albany, N. Y.

Tour, Sam, \& Co., Inc., New York, N. Y.

Twining Laboratories, The, Fresno, Calif.

Typhoon Air Conditioning Co., Inc., Brooklyn,

United States Testing Co., Inc., Hoboken, N. J.

Van Pelt, John V., Patchogue, N. Y.

Velde Lumber Co., Pekin, Ill.

Washington State College, Pullman, Wash.

Welch, Carroll E., Huntington, N. Y.

West, Albert E., Boston, Mass.

White Bros. Smelting Corp., Philadelphia, $\mathrm{Pa}$.

Wichita Ice \& Cold Storage Co., The, Wichita, Kans.

Wight \& Wight, Kansas City, Mo.

Willatsen, Andrew, Seattle, Wash.

Williams \& Co., Inc., Pittsburgh, Pa.

Williams, A. W., Inspection Co., Mobile, Ala.

Williams, Bruce, Laboratories, Joplin, Mo.

Wood Construction \& Building Matcrialist, Xenia, Ohio.

Wright, Wm. Camp bell, Chicago, Ill.

Wright \& Wright, Detroit, Mich. (General support).

Zimmerman, A. C., Los Angeles, Calif.

\section{UNITED STATES GOVERNMENT}

Agriculture, U. S. Department of, Division of Purchase, Sales \& Traffic, Washington, D. C.

Federal Works Agency, Public Buildings Administration, Washington, D. C. (General support.)

Naval Base, Public Works Department, Philadelphia, Pa. 


\section{COMMERCIAL STANDARDS}

CS No. Item

0-40. Commercial standards and their value to business (third edition).

1-42. Clinical thermometers (third edition).

2-30. Mopsticks.

3-40. Stoddard solvent (third edition)

4-29. Staple porcelain (all-clay) plumbing fixtures.

5-46. Pipe nipples; brass, copper, steel and wroughtiron (second edition).

$6-31$. Wrought-iron pipe nipples (second edition). Superseded by CS5-46.

7-29. Standard weight malleable iron or steel screwed unions.

8-41. Gage blanks (third edition).

9-33. Builders' template hardware (second edition).

10-29. Brass pipe nipples. Superseded by CS5-46.

11-41. Moisture regains of cotton yarns (second edition).

12.48. Fuel oils (sixth edition).

13-44. Dress patterns (fourth edition).

14-43. Boys' button-on waists, shirts, junior and sport shirts (made from woven fabrics) (third edition).

15-46. Men's pajama sizes (made from woven fabrics) (third edition).

16-29. Wall paper.

17-47. Diamond core drill fittings (fourth edition). 18-29. Hickory golf shafts.

19-32. Foundry patterns of wood (second edition).

20-47. Staple vitreous china plumbing fixtures (fourth edition).

21-39. Interchangeable ground-glass joints, stopcocks, and stoppers (fourth edition).

22-40. Builders' hardware (nontemplate) (second edition).

23-30. Feldspar.

24-43. Screw threads and tap-drill sizes.

25-30. Special screw threads. Superseded by CS24-

26-30. Aromatic red cedar closet lining.

27-36. Mirrors (second edition).

28-46. Cotton fabric tents, tarpaulins and covers (sccond edition)

29-31. Staple seats for water-closet bowls.

30-31. Colors for sanitary ware. (Withdrawn as commercial standard March 15, 1948.)

31-38. Wood shingles (fourth edition).

$32-31$. Cotton cloth for rubber and pyroxylin coating.

33-43. Knit underwear (exclusive of rayon) (second edition).

34-31. Bag, case, and strap leather.

35-47. Hardwood plywood (third edition).

36-33. Fourdrinier wire cloth (second edition).

37-31. Steel bone plates and screws.

38-32. Hospital rubber sheeting.

39-37. Wool and part-wool blankets (second edition). (Withdrawn as commercial standard, July 14, 1941.)

40-32. Surgeons' rubber gloves.

41-32. Surgeons' latex gloves.

42-43. Structural fiber insulating board (third edition).

43-32. Grading of sulphonated oils.

44-32. Apple wraps.

45-48. Douglas fir plywood (eighth edition).

46-40. Hosiery lengths and sizes (third edition).

47-34. Marking of gold-filled and rolled-gold-plate articles other than watchcases.

48-40. Domestic burners for Pennsylvania anthracite (underfeed type) (second edition).

49-34. Chip board, laminated chip board, and miscellaneous boards for bookbinding purposes.

50-34. Binder's board for bookbinding and other purposes.

51-35. Marking articles made of silver in combination with gold.

52-35. Mohair pile fabrics (100-percent mohair plain velvet, 100-percent mohair plain frieze, and 50-percent mohair plain frieze).

53-35. Colors and finishes for cast stone.

$54-35$. Mattresses for hospitals.

55-35. Mattresses for institutions.
CS No.

Item

56-41. Oak flooring (second edition).

57-40. Book cloths, buckrams, and impregnated fabrics for bookbinding purposes except library bindings (second edition).

58-36. Woven elastic fabrics for use in overalls (overall elastic webbing).

59-44. Textiles-testing and reporting (fourth edition).

60-48. Hardwood dimension lumber (second edition).

61-37. Wood-slat venetian blinds.

62-38. Colors for kitchen accessories.

63-38. Colors for bathroom accessories.

64-37. Walnut veneers.

65-43. Methods of analysis and of reporting fiber composition of textile products (second edition).

66-38. Marking of articles made wholly or in part of platinum.

67-38. Marking articles made of karat gold.

68-38. Liquid hypochlorite disinfectant, deodorant, and germicide.

69-38. Pine oil disinfectant.

70-41. Phenolic disinfectant (emulsifying type) (second edition) (published with CS71-41).

71-41. Phenolic disinfectant (soluble type) (second edition) (published with CS70-41)

72-38. Household insecticide (liquid spray type).

73-48. Old growth Douglas fir, Sitka spruce, and Western hemlock standard stock doors (fourth edition).

74-39. Solid hardwood wall paneling.

75-42. Automatic mechanical draft oil burners designed for domestic installations (second edition).

76-39. Hardwood interior trim and molding.

77-48. Enameled cast-iron plumbing fixtures (second edition).

78-40. Ground-and-polished lenses for sun glasses (second edition) (published with CS79-40).

79-40. Blown, drawn, and dropped lenses for sun glasses (second edition) (published with CS78-40)

80-41. Electric direction signal systems other than semaphore type for commercial and other vehicles subject to special motor vehicle laws (after market)

81-41. Adverse-weather lamps for vehicles (after market).

82-41. Inner-controlled spotlamps for vehicles (after market).

83-41. Clearance, marker, and identification lamps for vehicles (after market).

84-41. Electric tail lamps for vehicles (after market).

85-41. Elcctric license-plate lamps for vehicles (after market).

86-41. Electric stop lamps for vehicles (after market).

$87-41$. Red electric warning lanterns.

88-41. Liquid burning flares.

89-40. Hardwood stair treads and risers.

90-. (Reserved for power shovels and cranes).

91-41. Factory-fitted Douglas fir entrance doors.

92-41. Cedar, cypress, and redwood tank stock lumber.

93-41. Portable electric drills (exclusive of high frequency).

94-41. Calking lead.

95-41. Lead pipe.

96-41. Lead traps and bends.

97-42. Electric supplementary driving and passing lamps for vehicles (after market).

98-42. Artists' oil paints.

99-42. Gas floor furnaces-gravity circulating type.

100-47. Porcelain-enameled steel utensils (third edition).

101-43. Flue-connected oil-burning space heaters equipped with vaporizing pot-type burners.

102- . (Reserved for Diesel and fuel-oil engines)

103-48. Rayon jacquard velour (with or without other decorative yarn) (second edition).

104-46. Warm-air furnaces equipped with vaporizing pot-type oil burners (second edition). 
Cs No. Item

105-48. Mineral wool insulation for low temperatures (second edition).

106-44. Boys' pajama sizes (woven fabrics) (second edition).

107-45. Commercial electric-refrigeration condensing units (second edition). (Withdrawn as commercial standard September 4,1947 .)

108-43. Treading automobile and truck tires.

109-44. Solid-fuel-burning forced-air furnaces.

110-43. Tire repairs-vulcanized (passenger, truck, and bus tires).

111-43. Earthenware (vitreous-glazed) plumbing fixtures.

112-43. Homogeneous fiber wallboard.

113-44. Oil-burning floor furnaces equipped with vaporizing pot-type burners.

114-43. Hospital sheeting for mattress protection.

115-44. Porcelain-enameled tanks for domestic use.

116-44. Bituminized-fibre drain and sewer pipe.

117-44. Mineral wool; blankets, blocks, insulating cement, and pipe insulation for heated industrial equipment.

118-44. Marking of jewelry and novelties of silver.

(E) 119-45.1 Dial indicators (for linear measurements).

120-48. Standard stock ponderosa pine doors (third edition).

121-45. Women's slip sizes (woven fabrics).

122-45. Western hemlock plywood.

$123-45$. Grading of diamond powder.

(E) 124-45.1 Master disks.

125-47. Prefabricated homes (second edition).

126-45. Tank-mounted air compressors.

127-45. Self-contained mechanically refrigerated drinking water coolers.

128-45. Men's sport shirt sizes-woven fabrics (other than those marked with regular neckband sizes).
CS No. Item

129-47. Materials for safety wearing apparel (second edition).

130-46. Color materials for art education in schools. 131-46. Industrial mineral wool products, all typestesting and reporting.

132-46. Hardware cloth

133-46. Woven wire netting.

134-46. Cast aluminum cooking utensils (metal composition).

135-46. Men's shirt sizes (exclusive of work shirts)

136-46. Blankets for hospitals (wool, and wool and cotton).

137-46. Size measurements for men's and boys' shorts (woven fabrics)

138-47. Insect wire screening.

139-47. Work gloves.

140-47. Testing and rating convectors.

141-47. Sine bars, blocks, plates, and fixtures.

142-47. Automotive lifts.

143-47. Standard strength and extra strength perforated clay pipe.

144-47. Formed metal porcelain enameled sanitary ware.

145-47. Testing and rating hand-fired hot-watersupply boilers.

146-47. Gowns for hospital patients.

147-47. Colors for molded urea plastics.

148-48. Men's circular flat and rib knit rayon underwear.

149-48. Utility type house dress sizes.

150-48. Hot-rolled rail steel bars (produced from teesection rails).

151-48. Body measurements for the sizing of apparel for infants, babies, toddlers, and children (for the knit-underwear industry).

152-48. Copper naphthenate wood-preservative.

1 Where "(E)" precedes the CS number, it indicates an emergency commercial standard, drafted under war conditions with a view toward early revision.

Notice.-Those interested in commercial standards with a view toward accepting them as a basis of everyday practice may secure copies of the above standards, while the supply lasts, by addressing the Commodity Standards Division, National Bureau of Standards, Washington 25, D. C. 